\title{
Sistem Pendeteksi Kesegaran Ikan Bandeng Menggunakan Citra
}

\author{
Indrabayu ${ }^{1}$, Muh. Niswar ${ }^{2}$, Andryanto $\mathrm{Aman}^{3}$ \\ ${ }^{1,2}$ Jurusan Teknik Elektro dan Teknik Informatika, Universitas Hasanuddin Makassar \\ ${ }^{3}$ Sistem Komputer, STMIK Handayani Makasar \\ ${ }^{3}$ J1. Adhyaksa Baru No.1 Makassar 90231 Sulawesi Selatan \\ Email korespondensi:indrabayu@unhas.ac.id
}

Dikirim 12 Oktober 2016, Direvisi 04 November 2016, Diterima 25 November 2016

\begin{abstract}
Abstrak - Penelitian ini bertujuan untuk mencari solusi terbaik dalam pemeriksaan kesegaran ikan bandeng pada usaha kecil menengah. Teknik pemeriksaan kesegaran ikan bandeng selama ini masih ditentukan dengan cara analisis mikrobiologi dan kimiawi. Teknik ini dianggap kurang tepat dikarenakan selain membutuhkan banyak tenaga manusia yang rentan dalam melakukan kesalahan dan kelelahan fisik, juga membutuhkan biaya yang besar dan waktu yang lama, sehingga mempengaruhi produksi ikan bandeng. Dalam penelitian ini diusulkan suatu metode pengolahan citra dengan teknik mencari selisih nilai R, G, B pada citra referensi (latih) dengan citra masukan (uji) untuk selanjutnya nilai selisih tersebut dihitung dengan persamaan Euclidian (Length) dan dibandingkan dengan nilai threshold $(\mathrm{T})$. Data referensi yang digunakan adalah 5 ikan bandeng segar, Sehingga citra referensi yang dihasilkan pada posisi $\mathrm{R}=160, \mathrm{G}=35, \mathrm{~B}=35$ dan threshold $=55$. Dari pengujian terhadap 10 ikan Bandeng segar menghasilkan nilai deteksi sebesar 100\%, dan pengujian terhadap 10 ikan bandeng tidak segar menghasilkan nilai deteksi sebesar $80 \%$. Dan telah diuji hasil pengamatan nelayan dan alat deteksi kesegaran ikan Bandeng terhadap 30 sampel ikan segar, maka dihasilkan nilai deteksi ikan segar sebesar 100\% terhadap hasil pengamatan nelayan.
\end{abstract}

Kata kunci - Ikan Bandeng, Pengolahan Citra, Euclidian, Threshold.

Abstract - This research aims to find the best solution in examination of milkfish freshness on small businesses. Inspection techniques of milkfish freshness is still determined by means of the analysis of Microbiology and chemistry. This technique is considered less appropriate because in addition requires a lot of manpower which is vulnerable in doing physical fatigue and errors, also requires a large cost and time, thereby affecting the fish production of milkfish. In this research proposed a method of image processing with the technique of finding the difference in the value of $\mathrm{R}, \mathrm{G}, \mathrm{B}$ on the reference image (Trainer) and the input image (test) next to a value calculated by the difference equation of Euclidean (Length) and compared with the value of the threshold (T). Reference data used 5 fish fresh milkfish. So the resulting reference image at position $\mathrm{R}=160, \mathrm{G}=50 \mathrm{~B}=35$ and threshold $=55$, From the results of the experiment 10 fish fresh milkfish results $100 \%$ detection, and 10 fish not fresh milkfish experiment results $80 \%$ detection. and it has tested the observations of fishermen and fish freshness detection tool as many as 30 samples of fish fresh milkfish, then the resulting value of fresh fish detection of $100 \%$ of the observations of fishermen.

Keywords - Milkfish, image processing, Euclidean, Threshold.

\section{PENDAHULUAN}

Hasil produksi bandeng secara nasional saat ini menempati urutan ke-enam setelah Rumput laut, Patin, Nila, Lele, dan Udang. Catatan kementerian kelautan perikanan (KKP) menunjukkan produksi budidaya ikan yang dalam bahasa ilmiah dikenal dengan Chanos Chanos ini meningkat lebih dari $17 \%$ tiap tahunnya. Kasubdit Budidaya Air Payau Laut KKP, Setiawan menyampaikan keterangan, produksi Bandeng tahun 2012 tercatat 503.400 ton dan di tahun 2013 mencapai 604.000 ton, dan di perkirakan untuk tahun 2014 ini akan menembus 700.000 ton [1].
Seiring meningkatnya produksi akan konsumsi ikan segar, membuat orang yang tak bertanggung jawab memanfaatkan kondisi dengan menjual ikan yang tidak layak konsumsi seperti ikan busuk, ikan berklorin [2], dan berformalin [3]. Meski pemerintah sudah memberi larangan keras berdasarkan UU No 7 Tahun 1996 tentang Pangan pada pasal 21 huruf e, ditegaskan bahwa setiap orang dilarang mengedarkan pangan yang sudah kadaluwarsa [4], dan Peraturan Pemerintah RI Nomor 28 Tahun 2004 tentang keamanan, mutu dan gizi pangan, karena menjual makanan yang tidak layak dikonsumsi ancamannya berupa pidana penjara maksimal 5 tahun atau denda 
maksimal Rp 600 juta [5], tapi para pedagang tetap berbuat curang hanya untuk keuntungan mereka.

Pemeriksaan kesegaran Ikan khususnya Bandeng di UKM (Usaha Kecil Menengah), dapat dilakukan melalui analisis mikrobiologi dan kimiawi tetapi cara ini kurang efektif karena membutuh tenaga manusia yang tidak sedikit, membutuhkan biaya yang cukup mahal, membutuhkan waktu yang lebih lama dan juga manusia rentang dari kelelahan fisik, sehingga mempengaruhi produksi ikan. Maka dibutuhkan alat pendeteksi kesegaran ikan khusus pada Bandeng (Chanos - chanos) dalam hal ini penanganan ikan dengan jumlah yang banyak menggunakan citra sebagai pendeteksi kesegaran ikan berdasarkan parameter pengujian pada kepala dan sebagian tubuh ikan.

Metode yang digunakan sebelumnya untuk mengukur kesegaran ikan diantara adalah "aplikasi metode akustik untuk menguji kesegaran ikan" [6]. Metode ini memanfaatkan pulsa gelombang suara yang dipancarkan dan diterima oleh transduser untuk mengetahui kondisi atau karakteristik pantulan suara terhadap terhadap target yang diamati. Penelitan ini masih bersifat mengamati kemunduran dari mutu ikan Patin. Selain itu terdapat penelitian lainnya dari sistem penentuan kualitas ikan, yaitu " Penentuan kualitas kesegaran ikan dengan citra mata menggunakan metode Support Vector Machine" [7]. Penelitian ini mengklasifikasi kesegaran ikan dengan parameter citra mata ikan berdasarkan nilai mean, standard deviation, skewness, energy, entropy dan smoothness dari Histogram Warna dan metode Support Vector Machine sebagai pengklasifikasi. Dari hasil percobaan terhadap data citra mata ikan didapatkan tingkat akurasi dari Support Vector Machine metode OAO yaitu ikan dengan kualitas ikan segar $86,8 \%$, ikan dengan kualitas sedang $81,1 \%$ dan ikan busuk $81,1 \%$, dan OAA didapatkan tingkat akurasi ikan segar $92,2 \%$ ikan sedang $82,2 \%$ dan ikan busuk $82,2 \%$, sedangkan Backpropagation Neural Network didapatkan tingkat akurasi ikan segar 54,4\%, ikan kualitas sedang 54,4\% dan ikan busuk $74,4 \%$ Deteksi kesegaran ikan juga dilakukan oleh beberapa peneliti lain seperti "Deteksi kesegaran ikan dilihat dari warna insang menggunakan histogram warna" [10]. "Identifikasi kesegaran ikan menggunakan alih-ragam Wavelet yang digabungkan dengan algoritma JST(jaringan saraf tiruan)" oleh [11]. "Rancang bangun alat pengukuran kesegaran ikan menggunakan sensor infrared" oleh [12], serta "Klasifikasi kesegaran ikan Bandeng dalam smart packaging berbasis image processing menggunakan metode fuzzy" oleh [13].

Berdasarkan penelitian yang sudah ada perlu dikembangkan sistem deteksi kesegaran ikan Bandeng dengan parameter citra kepala dan sebagian tubuh ikan agar tingkat akurasi nya dapat lebih baik dari penelitian sebelumnya. Parameter dari kepala dan sebagian tubuh ikan Bandeng diolah oleh Raspberry menggunakan metode pengolahan citra dengan teknik mencari selisih nilai R, G, B pada citra referensi (latih) dengan citra masukan (uji) untuk selanjutnya nilai selisih tersebut dihitung dengan persamaan Euclidian (Length) dan dibandingkan dengan nilai threshold (T). Selain penentuan kualitas ikan segar, hal yang baru dari penelitian ini adalah alat prototype konveyor yang dapat mendekteksi ikan dalam jumlah banyak.

\section{METODOLOGI PENELITIAN}

Fokus dari penelitian ini merancang sistem pendeteksi kesegaran ikan Bandeng menggunakan citra. Penelitian ini diharapkan dapat membantu UKM (usaha kecil menengah) dalam memproduksi ikan segar.

Pada penelitian ini terdapat arsitektur sistem yang saling terhubung yaitu input, proses dan output. Input dari sistem ini adalah data image berupa gambar ikan yang ditangkap oleh kamera kemudian diolah menggunakan image processing sehingga dapat dirubah menjadi nilai bit. Proses dari sistem ini menggunakan Raspberry $\mathrm{Pi}$ dan mikrokontroler ATMega16, sedangkan output dari sistem ini adalah bagaimana sistem dapat mendeteksi kesegaran ikan. Pada Gambar 1 ditunjukkan diagram blok sistem dan pada Gambar 2 ditunjukkan flowchart program sistem.

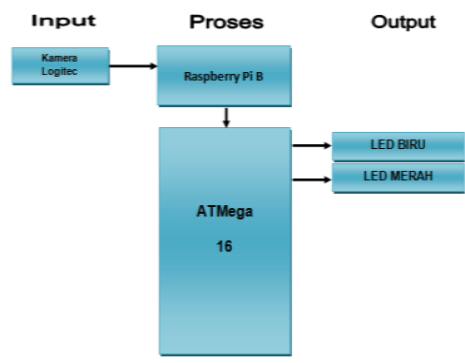

Gambar 1. Diagram Blok Sistem

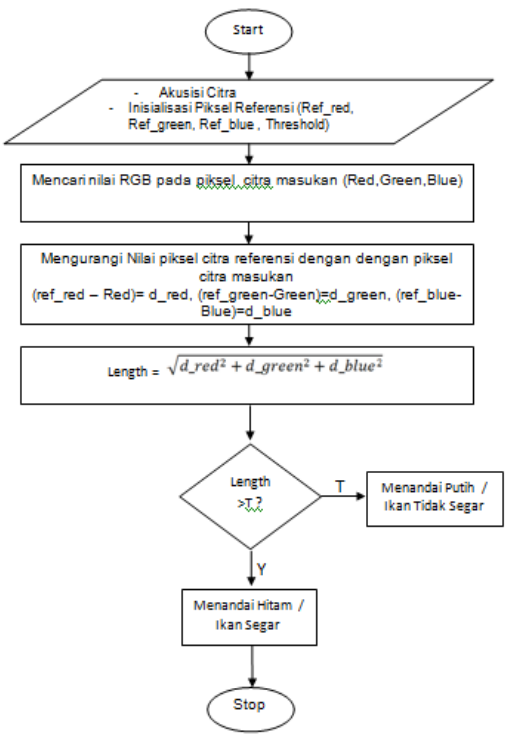

Gambar 2. Flowchart Program Deteksi Kesegaran Ikan 
Penjelasan flowchart program.

- Akusisi citra, dimana kamera mengambil gambar.

- Inisialisasi piksel referensi

- Mencari nilai RGB pada piksel citra masukan (Red, Green, Blue), dimana program akan mencari nilai Red, Green, Blue pada piksel 240 $\mathrm{x} 120$, setelah nilai RGB sudah ditentukan, maka selanjutnya.

- Mengurangi nilai piksel citra referensi dan nilai citra masukan, dimana nilai piksel citra referensi adalah Ref_red $=160$, Ref_green $=$ 35, Ref_blue $=35$ dikurangi nilai piksel citra masukan, yang menghasilkan nilai d_red, $\mathrm{d} \_$green, $\mathrm{d} \_$blue.

- Hasil selisi dari piksel citra referensi dan piksel citra masukan masing-masing nilai d_red, d_green, d_blue di pangkatkan 2, setelah itu dijumlahkan nilai d_red, d_green, d_blue, dan terakhir diakarkan, dan menghasilkan nilai length.

- Jika kondisi Length lebih besar dari nilai ambang 55 (Threshold) maka akan menandai hitam jika tidak menandai putih.

Contoh kasus ikan segar dan ikan tidak segar.

a) Ikan Segar

Diketahui nilai referensi

ref_red $=160$

ref_green $=35$

ref_blue $=35$

$\mathrm{t}=55$

Misalkan nilai piksel masukan ikan segar, red = 90, green $=15$, blue $=15$.

Length $=\sqrt{(160-90)^{2}+(35-15)^{2}+(35-15)^{2}}$

Length $=\sqrt{70^{2}+25^{2}+25^{2}}$

Length $=\sqrt{4900+625+625}$

Length $=\sqrt{6150}$

Length $=78,42>55=$ menandai hitam (ikan segar)

b) Ikan tidak segar

Diketahui nilai referensi

ref_red $=160$

ref_green $=35$

ref_blue $=35$

$\mathrm{t}=55$

Misalkan nilai piksel masukan ikan tidak segar segar, red $=150$, green $=20$, blue $=20$.

Length $=\sqrt{(160-150)^{2}+(35-20)^{2}+(35-20)^{2}}$

Length $=\sqrt{10^{2}+15^{2}+15^{2}}$

Length $=\sqrt{100+225+225}$

Length $=\sqrt{550}$

Length $=23,45>55=$ menandai putih (ikan tidak segar )

\section{HASIL DAN PEMBAHASAN}

\section{A. Hasil Penelitian}

Berdasarkan perancangan yang ada, alat penentuan kualitas ikan Bandeng dirancang memiliki ukuran panjang $122 \mathrm{Cm}$, lebar $25 \mathrm{Cm}$ dan tinggi 23 $\mathrm{Cm}$. Adapun bahan yang digunakan untuk membuat mesin adalah alumunium, tripleks dan acrylic. Sistem terbuat dari beberapa bagian yang saling terhubung yaitu kamera sebagai alat pengambil gambar ikan, konveyor sebagai alat yang menampung ikan yang akan dideteksi kesegarannya, komponen elektronika yang terdiri dari power supply, sensor LDR, led, driver relay, raspberry pi sebagai alat pemroses data citra ikan dan mikrokontroler sebagai pengontrol sistem.

Sistem dirancang untuk dapat menentukan kualitas ikan bandeng segar atau tidak segar, jika pengguna ingin menentukan kualitas ikan tersebut cukup memasukkan ikan ke tempat ikan lalu menekan tombol switch pada konveyor, konveyor akan berjalan hingga sensor LDR akan mendeteksi keberadaan tempat ikan untuk menghentikan konveyor, lalu mikrokontroler mengirim data ke Raspberry Pi agar Raspberry $\mathrm{Pi}$ dapat memerintahkan kamera untuk mengambil gambar ikan Bandeng, setelah itu gambar tersebut akan diproses oleh Raspberry $\mathrm{Pi}$, hasil keputusan Raspberry $\mathrm{Pi}$ dikirim lagi ke mikrokontroler untuk menyalakan lampu indikator sebagai tanda segar (biru) atau busuk (merah) ikan Bandeng.

Semua komponen tersebut diintegrasikan sehingga terbentuk suatu sistem deteksi kesegaran ikan Bandeng menggunakan citra.

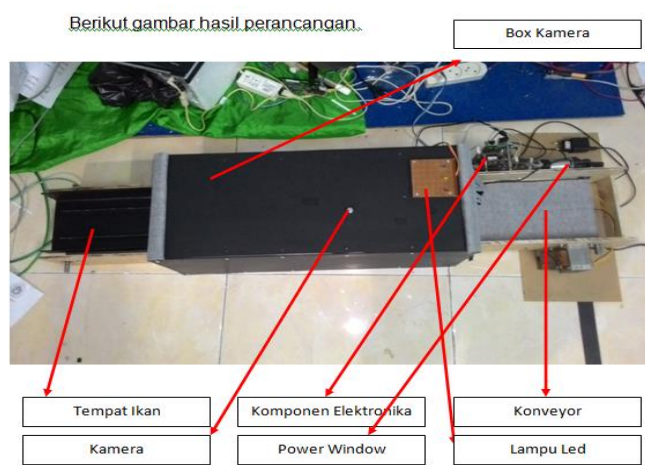

Gambar 3. Hasil Perancangan Sistem

\section{B. Data Training}

Penentuan nilai referensi dilakukan secara trial and error yang artinya dilakukan pengetesan beberapa kali terhadap 5 ekor ikan segar seperti yang ditunjukkan pada Gambar 4. Ikan segar adalah ikan yang masih mempunyai sifat sama seperti ikan hidup, baik rupa, bau, rasa, maupun teksturnya [14] untuk mendapatkan nilai rata-rata yang baik, yang nantinya akan digunakan untuk menentukan kesegaran ikan tersebut. 


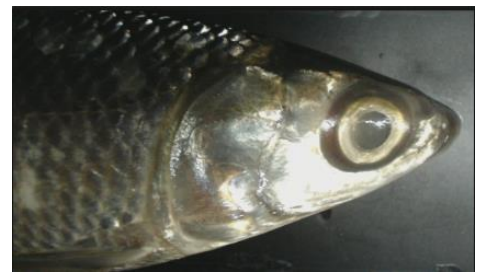

(4.a) Pengambilan Gambar Ikan Segar 1

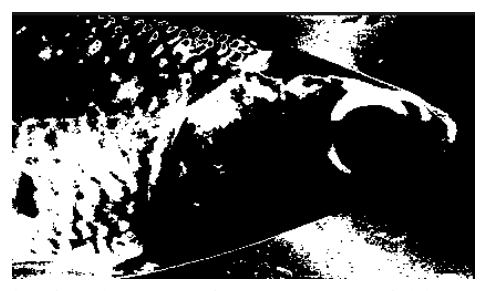

(4.a1) Nilai ref_red $=90$, ref_green $=35$, ref_blue $=35 \mathrm{~T}=55$ Pada Ikan 1

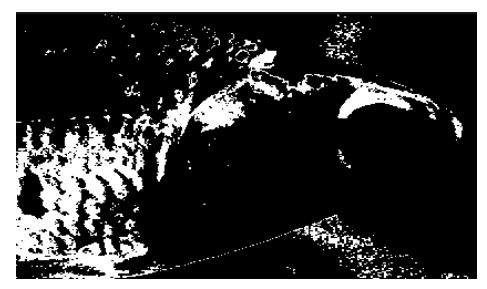

(4.a2) Nilai ref_red $=100$, ref_green $=35$, ref_blue $=35, T=55$ Pada Ikan 1

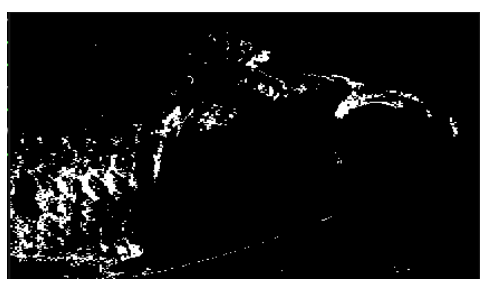

(4.a3) Nilai ref_red $=110$, ref_green $=35$, ref_blue $=35, \mathrm{~T}=55$ Pada Ikan 1

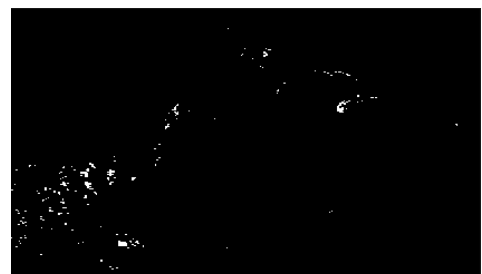

(4.a4) Nilai ref_red $=120$, ref_green $=35$, ref_blue $=35, \mathrm{~T}=55$ Pada Ikan 1

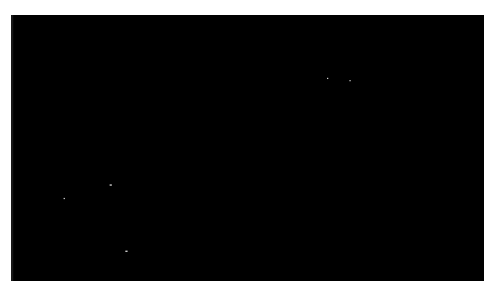

(4.a5) Nilai ref_red $=130$, ref_green $=35$, ref_blue $=35, \mathrm{~T}=55$ Pada Ikan 1

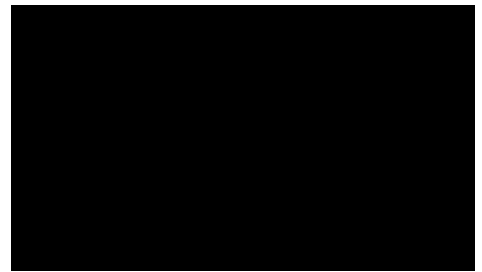

(4.a6) Nilai ref_red $=140$, ref_green $=35$, ref_blue $=35, \mathrm{~T}=55$ Pada Ikan 1

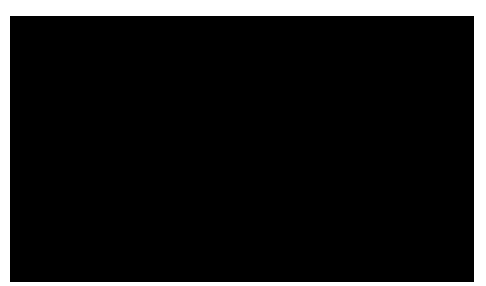

(4.a7) Nilai ref_red $=150$, ref_green $=35$, ref_blue $=35, \mathrm{~T}=55$ Pada Ikan 1

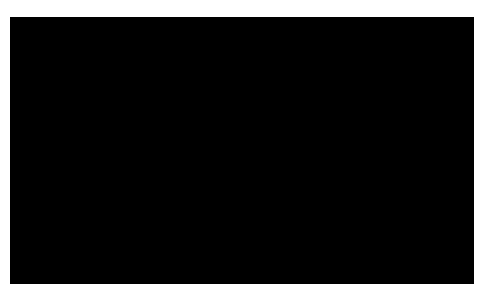

(4.a8) Nilai ref_red $=160$,ref_green $=35$, ref_blue $=35, \mathrm{~T}=55$ Pada Ikan 1

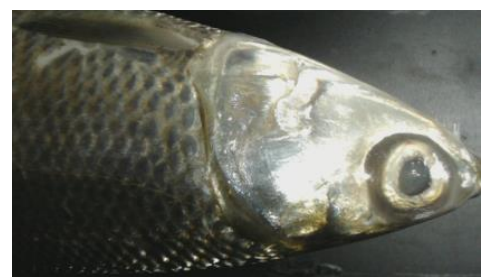

(4.b) Pengambilan Gambar Ikan 2

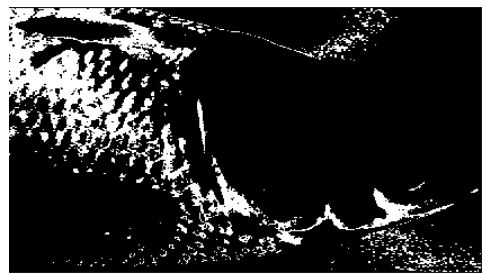

(4.b1) Nilai ref_red $=100$, ref_green $=35$, ref_blue $=35, \mathrm{~T}=55$ Pada Ikan 2

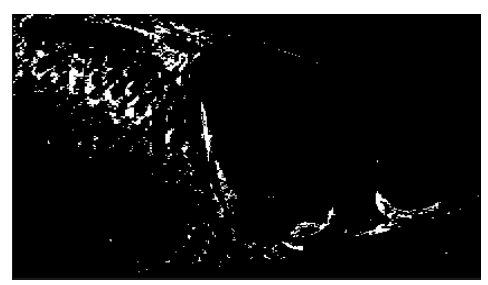

(4.b2) Nilai ref_red $=110$,ref_green $=35$, ref_blue $=35, \mathrm{~T}=55$ Pada Ikan 2 


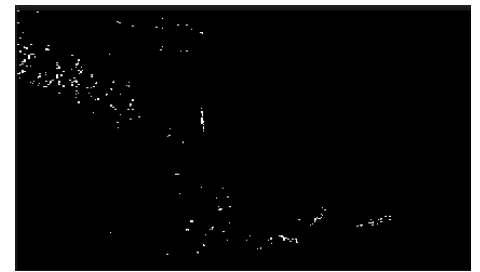

(4.b3) Nilai ref_red $=120$, ref_green $=35$, ref_blue $=35, \mathrm{~T}=55$ Pada Ikan 2

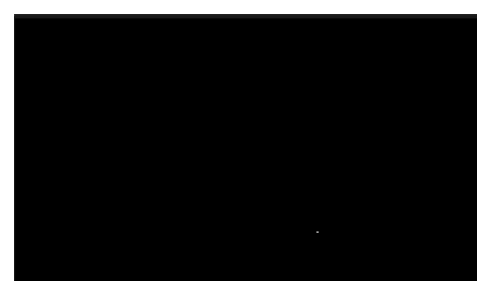

(4.b4) Nilai ref_red $=130$,ref_green $=35$, ref_blue $=35, \mathrm{~T}=55$ Pada Ikan 2

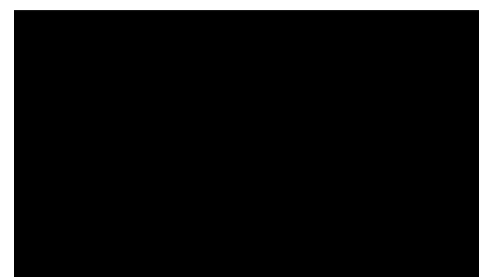

(4.b5) Nilai ref_red $=140$, ref_green $=35$, ref_blue $=35, \mathrm{~T}=55$ Pada Ikan 2

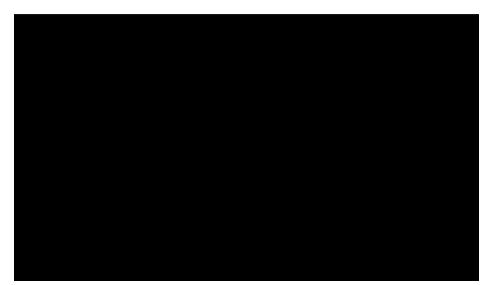

(4.b6) Nilai ref_red $=150$, ref_green $=35$, ref_blue $=35, \mathrm{~T}=55$ Pada Ikan 2

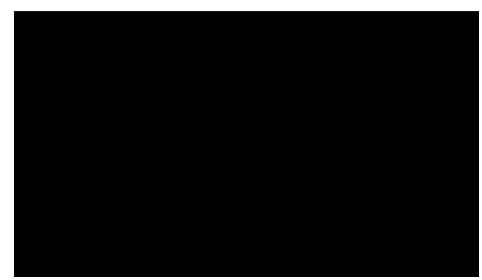

(4.b7) Nilai ref_red $=160$, ref_green $=35$, ref_blue $=35, \mathrm{~T}=55$ Pada Ikan 2

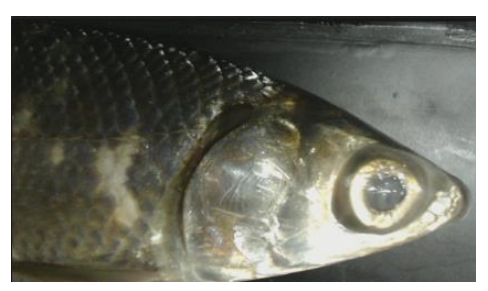

(4.c) Pengambilan Gambar Ikan 3

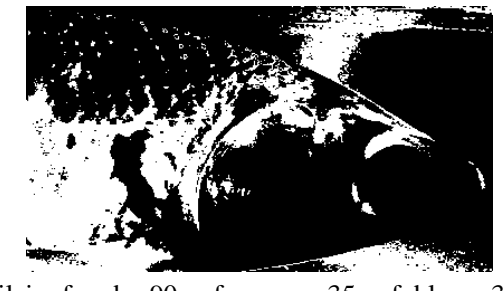

(4.c1) Nilai ref_red $=90$, ref_green $=35$, ref_blue $=35, \mathrm{~T}=55$ Pada Ikan 3

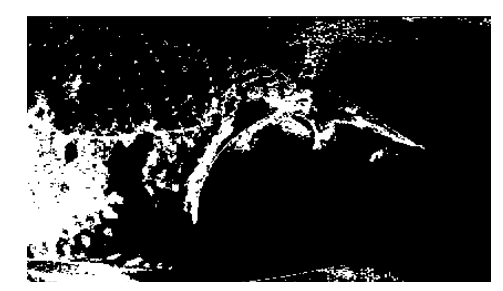

(4.c2) Nilai ref_red $=100$, ref_green $=35$, ref_blue $=35, \mathrm{~T}=55$ Pada Ikan 3

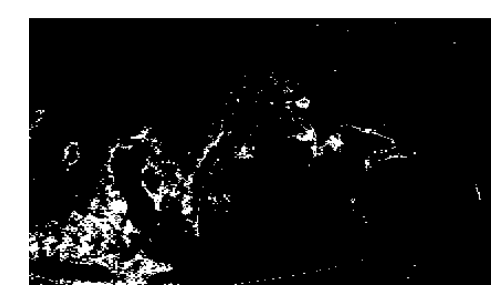

(4.c3) Nilai ref_red $=110$, ref_green $=35$, ref_blue $=35, \mathrm{~T}=55$ Pada Ikan 3

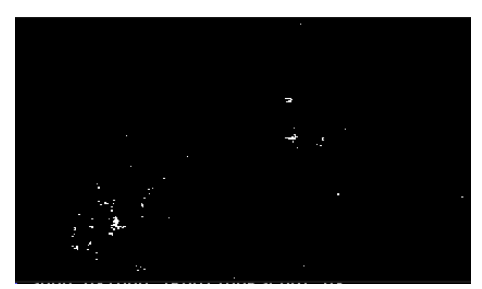

(4.c4) Nilai ref_red $=120$, ref_green $=35$, ref_blue $=35, \mathrm{~T}=55$ Pada Ikan 3

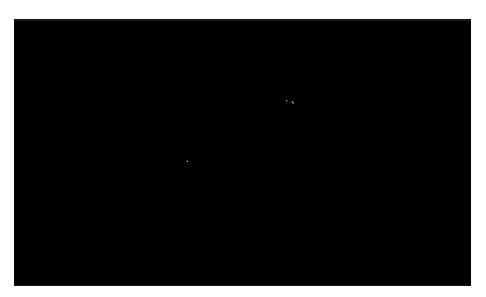

(4.c4) Nilai ref_red $=130$, ref_green $=35$, ref_blue $=35, \mathrm{~T}=55$ Pada Ikan 3

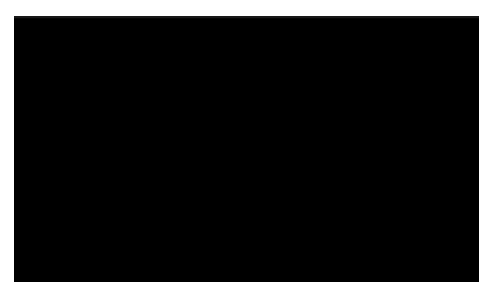

(4.c5) Nilai ref_red $=140$, ref_green $=35$, ref_blue $=35, \mathrm{~T}=55$ Pada Ikan 3 


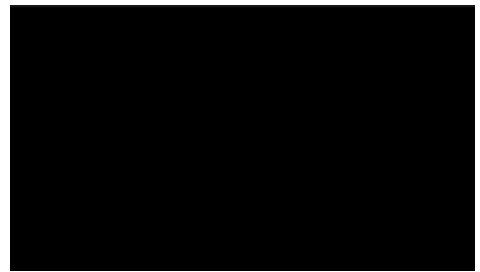

(4.c6) Nilai ref_red $=150$, ref_green $=35$, ref_blue $=35, \mathrm{~T}=55$ Pada Ikan 3

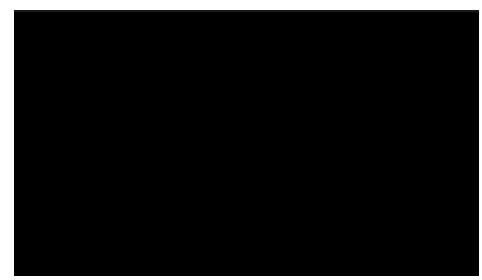

(4.c7) Nilai ref_red $=160$, ref_green $=35$, ref_blue $=35, \mathrm{~T}=55$ Pada Ikan 3

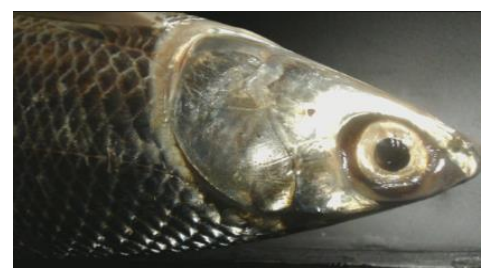

(4.d) Pengambilan Gambar Ikan 4

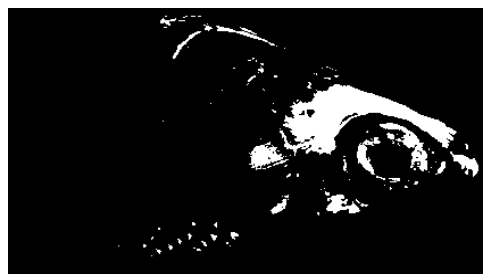

(4.d1) Nilai ref_red $=100$, ref_green $=35$, ref_blue $=35, T=55$ Pada Ikan 4

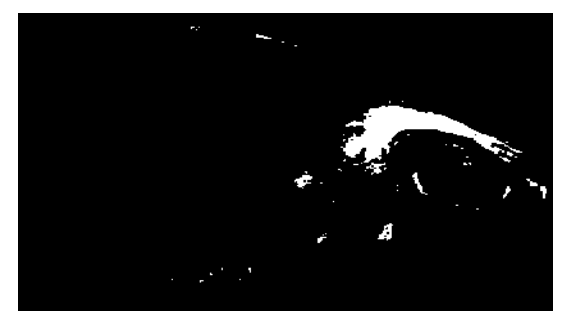

(4.d2) Nilai ref_red $=110$, ref_green $=35$, ref_blue $=35, T=55$ Pada Ikan 4

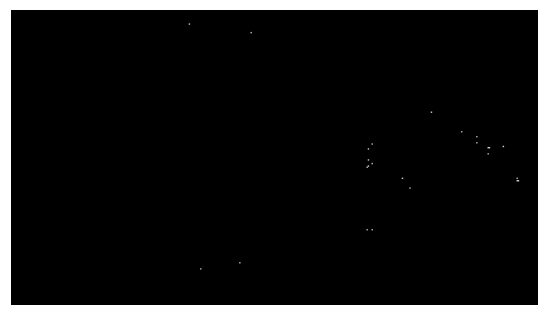

(4.d3) Nilai ref_red $=120$, ref_green $=35$, ref_blue $=35, T=55$ Pada Ikan 4

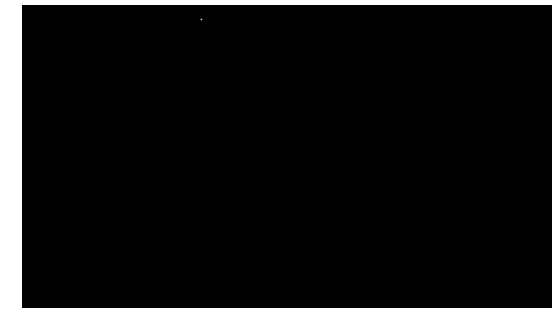

(4.d4) Nilai ref_red $=130$, ref_green $=35$, ref_blue $=35, T=55$ Pada Ikan 4

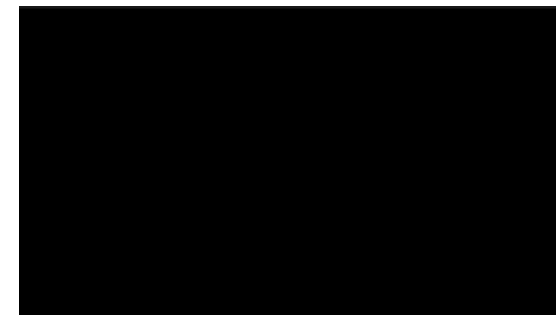

(4.d5) Nilai ref_red $=140$, ref_green $=35$, ref_blue $=35, \mathrm{~T}=55$ Pada Ikan 4

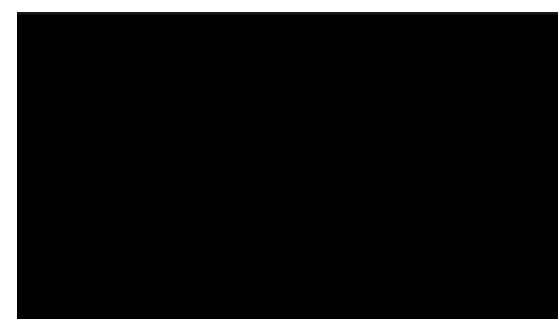

(4.d6) Nilai ref_red $=150$, ref_green $=35$, ref_blue $=35, \mathrm{~T}=55$ Pada Ikan 4

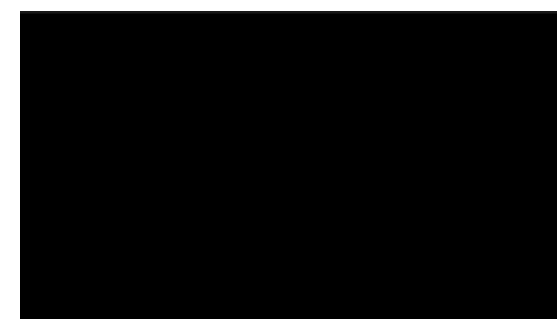

(4.d7) Nilai ref_red $=160$, ref_green $=35$, ref_blue $=35, \mathrm{~T}=55$ Pada Ikan 4

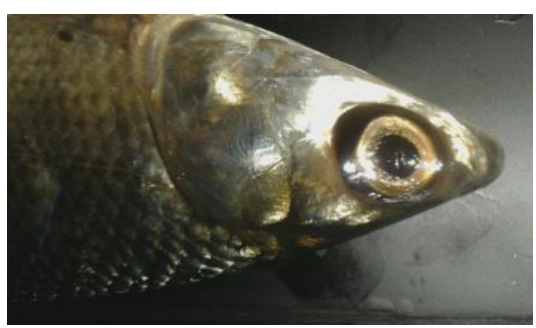

(4.e) Pengambilan Gambar 5 


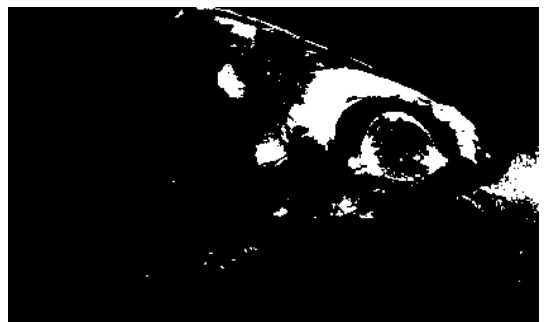

(4.e1) Nilai ref_red $=100$, ref_green $=35$, ref_blue $=35, \mathrm{~T}=55$ Pada Ikan 5

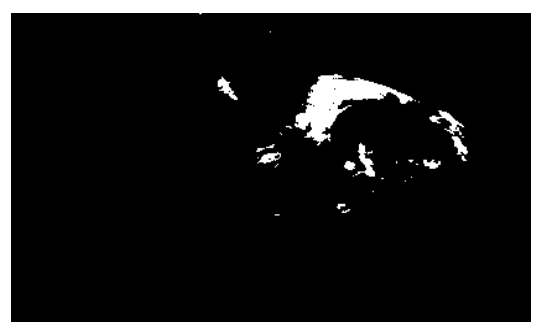

(4.e2) Nilai ref_red $=110$, ref_green $=35$, ref_blue $=35, \mathrm{~T}=55$ Pada Ikan 5

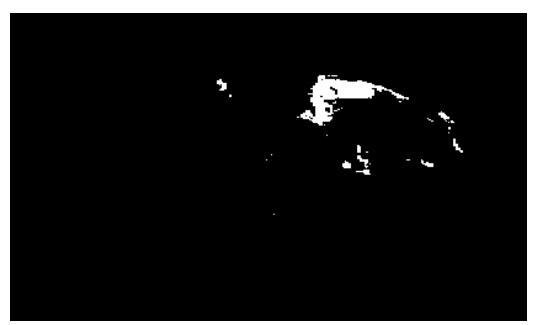

(4.e3) Nilai ref_red $=120$, ref_green $=35$, ref_blue $=35, \mathrm{~T}=55$ Pada Ikan 5

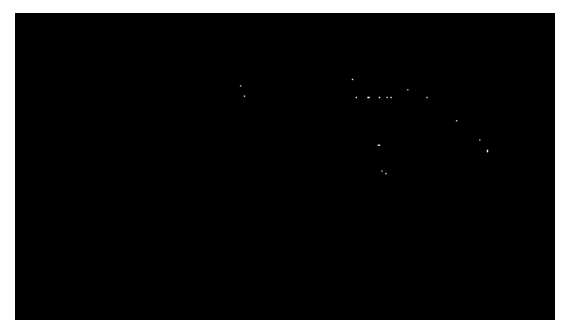

(4.e4) Nilai ref_red $=130$, ref_green $=35$, ref_blue $=35, \mathrm{~T}=55$ Pada Ikan 5

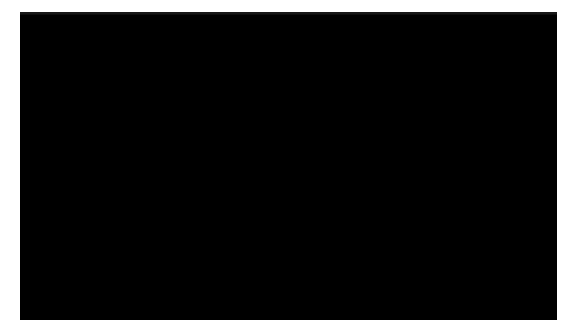

(4.e5) Nilai ref_red $=140$, ref_green $=35$, ref_blue $=35, \mathrm{~T}=55$ Pada Ikan 5

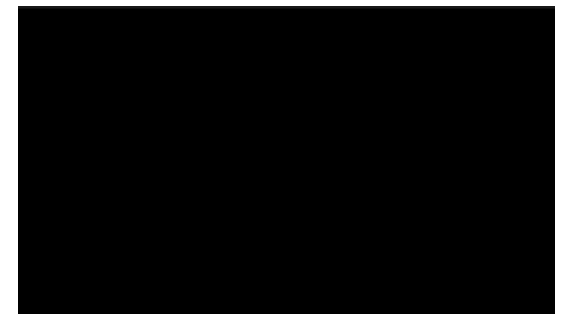

(4.e6) Nilai ref_red $=150$, ref_green $=35$, ref_blue $=35, \mathrm{~T}=55$ Pada Ikan 5

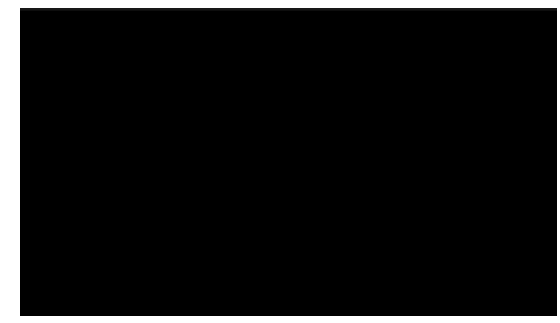

(4.e7) Nilai ref_red $=160$, ref_green $=35$, ref_blue $=35, \mathrm{~T}=55$ Pada Ikan 5

Gambar 4. Data Training Ikan Segar

Berdasarkan data training yang dilakukan secara trial and error yang artinya melakukan pengujian beberapa kali, dari 5 sampel ikan segar, rata-rata nilai referensi ref_red $=140$ tidak menimbulkan bercak putih, hingga nilai ref_red dinaikkan 160, sangat tidak menimbulkan bercak putih sedikitpun. Sehingga dalam pengujian ikan segar dan tidak segar kita dapat menggunakan nilai referensi red 140 sampai 160,untuk nilai referensi green dan blue adalah 35 .

\section{Pengujian}

Ikan segar (pre rigor) merupakan ikan yang belum mengalami perubahan fisik maupun kimia yang kondisinya masih seperti saat ikan ditangkap [8]. Sedangkan ikan tidak segar (post rigor) ikan yang sudah mengalami perubahan fisik seperti warna bagian mata kemerah-merahan, insang berwarna cokelat/suram, sisik mudah lepas [9]. Pengujian ini terbagi 2 yaitu pengujian deteksi ikan segar 10 sampel dan ikan tidak segar sebanyak 10 sampel .

a) Ikan segar dan hasil threshold

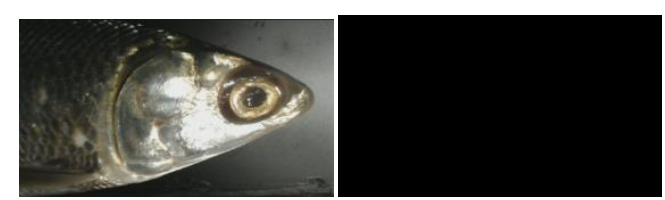

(5.a) Ikan Segar 1
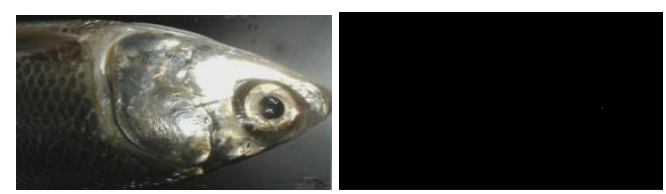

(5.b) Ikan Segar 2 
ISSN : 2085-3688; e-ISSN : 2460-0997

Sistem Pendeteksi Kesegaran Ikan Bandeng Menggunakan Citra
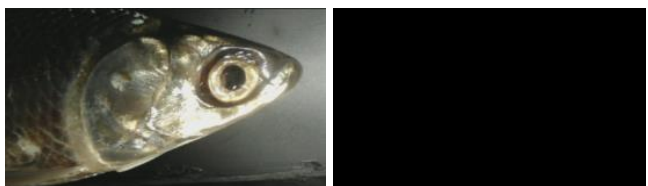

(5.c) Ikan Segar 3

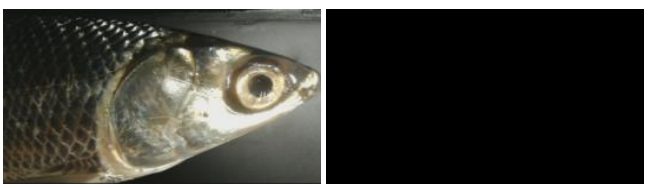

(5.d) Ikan Segar 4

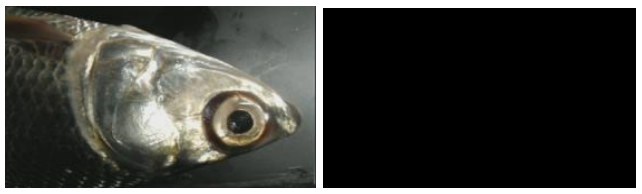

(5.e) Ikan Segar 5

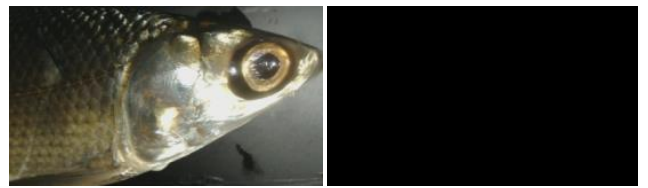

(5.f) Ikan Segar 6

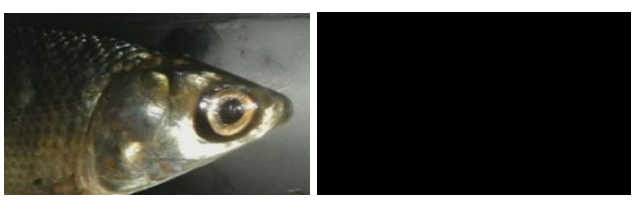

(5.g) Ikan Segar 7

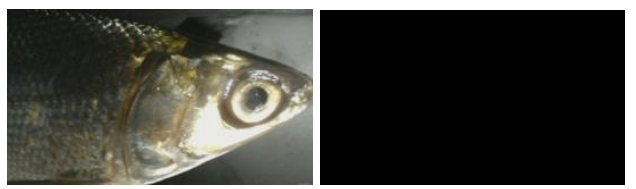

(5.h) Ikan Segar 8

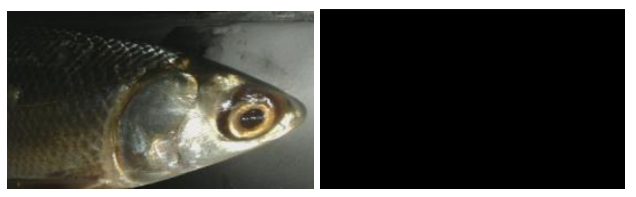

(5.i) Ikan Segar 9

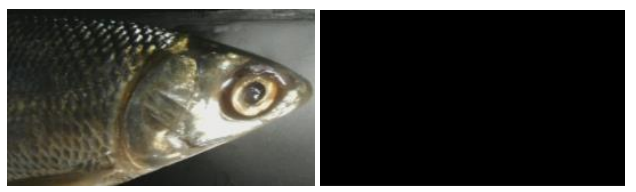

(5.j) Ikan Segar 10

Gambar.5 Hasil Pengujian Ikan Segar

Tabel 1. Hasil Pengujian Deteksi Kesegaran Ikan Menggunakan 10 Sampel Ikan Segar.

\begin{tabular}{ccc}
\hline \multirow{2}{*}{ No. } & \multicolumn{2}{c}{ Pengujian 10 Sampel } \\
\cline { 2 - 3 } & Segar & Tdk Segar \\
\hline 1 & $\sqrt{ }$ & - \\
2 & $\sqrt{ }$ & - \\
3 & $\sqrt{ }$ & -
\end{tabular}

\begin{tabular}{ccc}
\hline \multirow{2}{*}{ No. } & \multicolumn{2}{c}{ Pengujian 10 Sampel } \\
\cline { 2 - 3 } & Segar & Tdk Segar \\
\hline 4 & $\sqrt{ }$ & - \\
5 & $\sqrt{ }$ & - \\
6 & $\sqrt{ }$ & - \\
7 & $\sqrt{ }$ & - \\
8 & $\sqrt{ }$ & - \\
9 & $\sqrt{ }$ & - \\
10 & $\sqrt{ }$ &
\end{tabular}

Tabel 1 diatas menunjukkan tingkat akurasi pengujian sebesar $100 \%$ dalam mendeteksi ikan Bandeng segar.

b) Ikan tidak segar dan hasil threshold

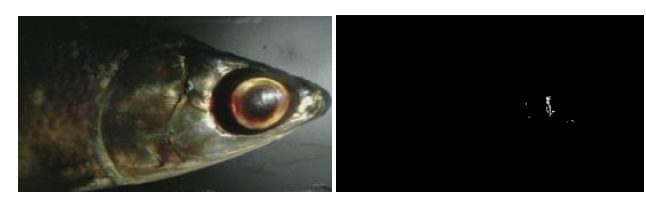

(6.a) Ikan Tidak Segar 1

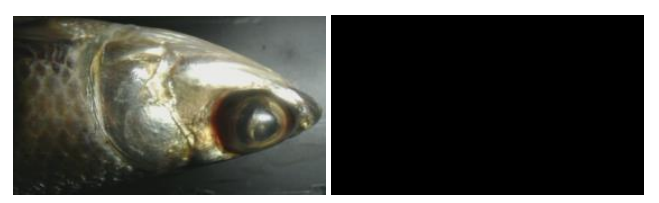

(6.b) Ikan Tidak Segar 2

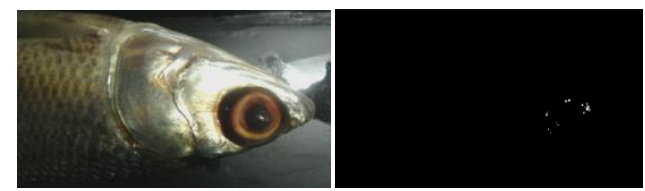

(6.c) Ikan Tidak Segar 3

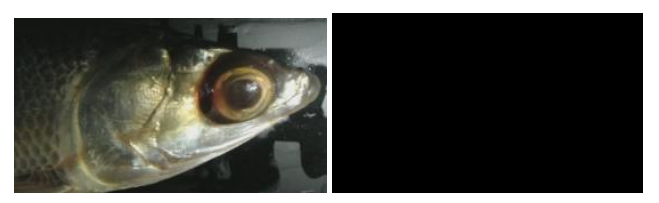

(6.d) Ikan Tidak Segar 4

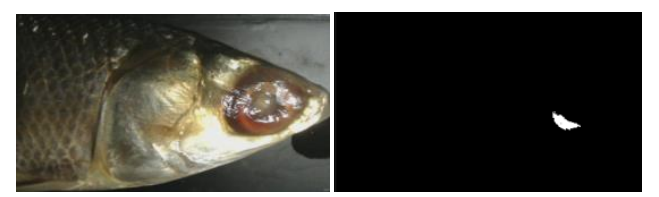

(6.e) Ikan Tidak Segar 5

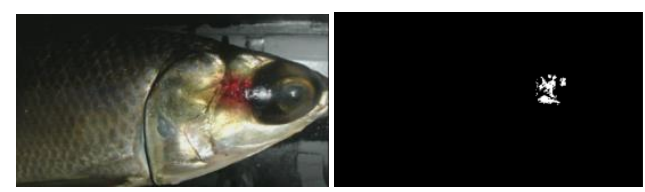

(6.f) Ikan Tidak Segar 6

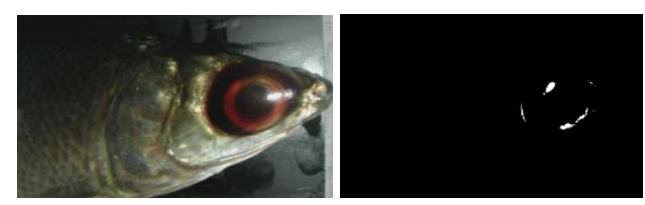

(6.g) Ikan Tidak Segar 7 


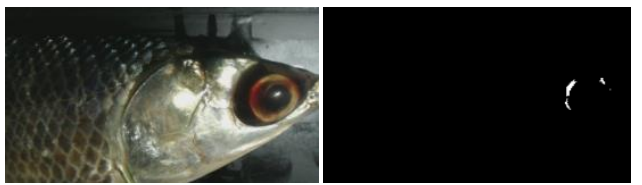

(6.h) Ikan Tidak Segar 8

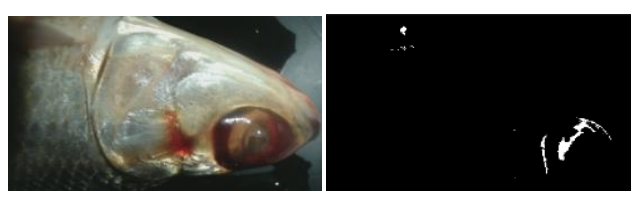

(6.i) Ikan Tidak Segar 9

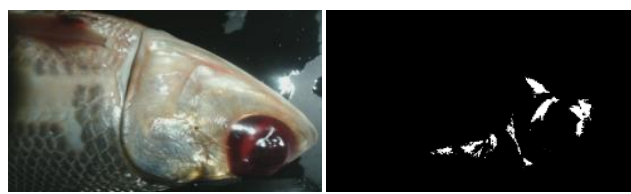

(6.j) Ikan Tidak Segar 10

Gambar 6. Hasil Pengujian Ikan Tidak Segar

Tabel 2. Hasil Pengujian Deteksi Kesegaran Ikan Menggunakan Sepuluh Sampel Ikan Tidak Segar

\begin{tabular}{ccc}
\hline \multirow{2}{*}{ No. } & \multicolumn{2}{c}{ Pengujian 10 Sampel } \\
\cline { 2 - 3 } & Segar & Tdk Segar \\
\hline 1 & - & $\sqrt{ }$ \\
2 & $\sqrt{ }$ & - \\
3 & - & $\sqrt{ }$ \\
4 & $\sqrt{ }$ & - \\
5 & - & $\sqrt{ }$ \\
6 & - & $\sqrt{ }$ \\
7 & - & $\sqrt{ }$ \\
8 & - & $\sqrt{ }$ \\
9 & - & $\sqrt{ }$ \\
10 & - & \\
\hline
\end{tabular}

Tabel 2 diatas menunjukkan tingkat akurasi pengujan sebesar $80 \%$ dalam mendeteksi ikan Bandeng yang tidak segar.

\section{Hasil Perbandingan Nelayan Dan Alat.}

Hasil perbandingan deteksi kesegaran ikan Bandeng yang dilakukan oleh nelayan dan alat pendeteksi kesegaran yang telah dibuat terhadap 30 sampel ikan segar menunjukkan bahwa deteksi kesegaran ikan Bandeng yang dilakukan oleh nelayan sama dengan hasil deteksi ikan Bandeng menggunakan alat deteksi yang dibuat yaitu sebesar $100 \%$ [9].

Berdasarkan dari hasil penelitian sistem pendeteksi kesegaran ikan Bandeng menggunakan citra membuktikan bahwa dengan menggunakan lebih dari satu parameter yaitu kepala dan sebagian badan ikan menunjukkan bahwa tingkat akurasinya lebih tinggi dibandingkan dengan penelitian sebelumnya yang menggunakan satu parameter yaitu mata ikan. Serta dapat mendeteksi ikan dalam jumlah yang banyak.

\section{PENUTUP}

\section{A. Kesimpulan}

Berdasarkan analisa dan hasil pengujian sistem pendeteksi kesegaran ikan Bandeng menggunakan citra, dapat ditarik kesimpulan sebagai berikut.

a) Bahwa dari hasil pengujian 10 sampel ikan segar menunjukkan bahwa akurasi sistem dalam mendeteksi kesegaran ikan mencapai $100 \%$ dan pengujian 10 sampel ikan tidak segar menunjukkan bahwa akurasi sistem dalam mendeteksi kesegaran ikan mencapai $80 \%$ pembacaan benar mendeteksi ikan tidak segar.

b) Dari perbandingan antara nelayan dan alat pendeteksi kesegaran ikan terhadap 30 sampel ikan yang dinyatakan oleh nelayan, alat dapat mendeteksi $100 \%$ ikan segar.

\section{B. Saran}

Adapun saran yang dapat diberikan adalah penelitian ini dapat dilanjutkan dengan menggunakan metode yang berbeda, dan menambahkan beberapa parameter agar hasil yang diperoleh dapat lebih akurat.

\section{DAFTAR PUSTAKA}

[1] Inforitel . Kebutuhan Ikan Bandeng Meningkat .http://inforitel.com/dpage.php?id=2\&autoid=10952 . Di akses 12 Agustus 2014.

[2] Trans TV . Jual ikan berklorin di pasar .https://www.youtube.com/watch?v=zZhq68FHxeY . Di akses 23 September 2014.

[3] Sudrajat, Achmad . Panen Bandeng 50 Hari . Penebar Swadaya. 2011.

[4] Republik Indonesia. 1996. Undang-Undang No.7 Tahun 1996 tentang Pangan. Lembaran Negara RI Tahun 1996, No.3656. Sekretariat Negara. Jakarta.

[5] Republik Indonesia. 2004. Peraturan Pemerintah No. 28 Tahun 2004 tentang Keamanan, Mutu dan Gizi Pangan. Lembaran Negara RI Tahun 2004, No. 4424. Sekretariat Negara. Jakarta.

[6] Jaya, I., Ramadhan, DK. 2006. Aplikasi Metode Akustik Untuk Uji Kesegaran Ikan . Buletin Teknologi Hasil Perikanan Vol IX .http://repository.ipb.ac.id/handle/123456789/14619 . Diakses 11 Agustus 2014.

[7] Arham . [, Purnama , I Ketut Eddy] , [, Purnomo , Mauridhi Heri] . Penentuan Kualitas Kesegaran Ikan dengan citra mata ikan menggunakan support vector Machine", jurnal teori dan aplikasi fisika, vol.1, no. 1,2013

ejournal.undip.ac.id/index.php/transmisi/article/view/6 986 .Diakses 25 agusyus 2014.

[8] Hakim, R.R. 2009. Pengolahan dan Pengawetan ikan.http://rizarahman.staff.umm.ac.id/files/2010/01/Pe ngolahan-ikan.pdf .Di akses 20 September 2015. 
[9] A, Andryanto . Perbandingan analisa nelayan dan alat pendeteksi kesegaran ikan bandeng (chanos-chanos) .https://youtu.be/Xln1OqLulA0 . Di akses 27 Oktober 2015.

[10] Saleh, dkk. 2014. Deteksi Kesegaran Ikan Dilihan Dari Warna Insang Menggunakan Histogram Warna. e prints repository software. http://eprints.ung.ac.id/8977/. Diakses 14 November 2016.

[11] Paniran. 2006. Pemrosesan citra mata ikan secara digital untuk menentukan kualitas kesegaran daging ikan. ejournal.ftunram.ac.id. Volume 7 No. 1. Juni 2006.

[12] Munandar, Erik. 2012. Rancang Bangun Alat Pengukuran Kesegaran Ikan Menggunakan Sensor Infrared. Scientific repository. http://repository.ipb.ac.id/handle/123456789/54269. Di akses 15 November 2015.

[13] Panjaitan, Ditaria. 2014. Klasifikasi kesegaran ikan bandeng dalam smart packaging berbasis image processing menggunakan metode fuzzy. Universitas Jember Digital Repository. http://repository.unej.ac.id/handle/123456789/19250. Di akses 18 November 2016.

[14] Usaha Umkm. 2015. Faktor-faktor yang menentukan mutu ikan http://www.usahaumkm.com/2015/04/faktor-faktoryang-menentukan-mutu-ikan.html. Di akses 18 November 2016. 